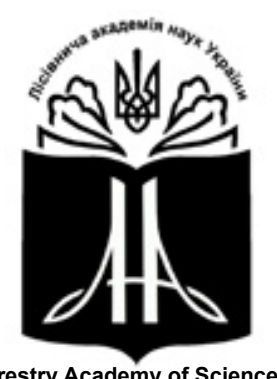

Forestry Academy of Sciences of Ukraine

Наукові праці Лісівничої академії наук України Proceedings of the Forestry Academy of Sciences of Ukraine

http://fasu.nltu.edu.ua https://doi.org/10.15421/411904

Article received 2018.10.16

Article accepted 2019.03.28
ISSN 1991-606X print

ISSN 2616-5015 online

(a) $\triangle$ Correspondence author

Volodymyr Zaika

vkzaika@ukr.net

General Chuprynka st., 103, Lviv, 79057, Ukraine

УДК $631 * 2:[630 * 177.952](477.84)$

\title{
Лісовідновні процеси в дубових деревостанах за участю липи дрібнолистої в умовах Західного Поділля
}

\author{
В. К. Заїка', Ю.С. Каленюк²
}

Досліджено лісовідновні процеси в 41-100-річних дубових деревостанах за участю липи дрібнолистої та на зрубах 1-5-річного віку в умовах свіжої грабової діброви Західного Поділля. Частка дуба і липи в їхньому складі коливається від поодиноких дерев до 10 одинищь. Встановлено, що природне поновлення в деревостанах проходить переважно незадовільно. Загальна кількість підросту деревних видів змінюється в межсах від 1,13 до 10,27 тис. екз./га. У його видовому складі трапляються дуби звичайний і червоний, ясен звичайний, клен гостролистий, клен-явір, в'яз голий, граб звичайний, липа дрібнолиста, горобина звичайна і бук лісовий. У віковій структурі на більшості дослідних ділянок домінуе 1-3-річний підріст. У $59 \%$ деревостанів його частка становить 50-100\%, а в інших коливається в межах 28,6-48,4\%. Серед деревних видів найкраще поновлюються клен гостролистий, клен-явір, граб звичайний та в'яз голий, підріст яких під наметом материнських деревостанів досягає 4-8-річного віку і більше. Підріст дуба звичайного 1-3-річного віку виявлено на 72,3\% ділянок, де його кількість становить 0,25-2,63 тис. екз./га. Підріст липи насіннєвого походження трапляється в 45,5\% дослідних деревостанів у кількості 0,25-1,38 тис. екз./га з часткою у складі 5,6-35,0\%. Кількість дрібного підросту на різних ділянках коливається в межах від 50 до 100\%. У деревостанах переважає середньо ослаблений (41,1-54,1\%) та значною мірою представлений дуже ослаблений (19,1-41,8\%) підріст деревних видів. Частка здорового підросту коливається у межах 14,0-30,5\%. Трапляння підросту в деревостанах становить 30-95\%. Серед деревних видів найнижчими показниками трапляння характеризується підріст липи дрібнолистої. Природне насіннсве поновлення липи дрібнолистої виявлено на 38\% від кількості обстежених 1-5-річних зрубів. Його кількість становить 55-275 екз./га. Середня висота підросту липи збільшується з віком: від 13,2 см на 1-річних до 40,6 см - на 5-річних зрубах. Життєздатність горішків липи в різні роки досліджень залишається переважно високою і варіює від 55 до $94 \%$.

Ключові слова: самосів; підріст; життєздатність горішків; трапляння; фізіологічний стан; видовий склад.

Вступ. Лісовий фітоценоз формується впродовж десятків років як сукупність деревних, кущових і трав'яних видів, часто різних за біологічними властивостями. Природне насіннєве поновлення в деревостанах пов'язане не тільки зі здатністю видів до інтенсивного плодоношення, але й їхнього потомства - до виживання в умовах низької інтенсивності світла. Липа дрібнолиста (Tilia cordata
Mill.), особливо іiї підріст, належить до найбільш тіневитривалих деревних видів (Murakhtanov, 1981). Вона характеризується щорічним плодоношенням (Hordienko, \& Karpenko,1996, Murakhtanov, 1981, Hordienko, Hoychuk, \& Hordienko, 1999). Однак, рясність урожаю залежать від умов середовища, причому високі врожаї реєструють у різних частинах ареалу липи через кожні 2-6 років, а середні - че-

Заїка Володимир Костянтинович - академік Лісівничої академії наук України, доктор біологічних наук, професор кафедри лісівництва. Національний лісотехнічний університет України, вул. генерала Чупринки, 103, м. Львів, 79057, Україна. Тел.: 032-258-42-80, +38-067-148-06-26. E-mail: vkzaika@ukr.net ORCID: https://orcid.org/0000-0002-6784-023

2 Каленюк Юрій Степанович - викладач, Кременецькиий лісотехнічний коледж, вул. Молодіжна 1, с. Білокриниця Тернопільської обл., 47014, Україна. Тел.: 035-46-52-404; +38-096-367-15-16. E-mail: kaleniukyurii@gmail.com 
рез рік (Hordienko, \& Karpenko, 1996, Murakhtanov, 1981, Hordienko, Hoychuk, \& Hordienko, 1999). У роки рясного плодоношення в липових деревостанах осипається більше 1 млн. горішків, а в періоди середньої урожайності - 500-700 тис. шт./га. В окремі роки урожайність чистих липняків Поволжя може досягати 100 кг/га (Murakhtanov, 1981). В умовах Лісостепу і Полісся України рясні врожаї липи повторюються 3 періодичністю в 2-3 роки (Hordienko, \& Karpenko, 1996, Hordienko, Hoychuk, \& Hordienko, 1999). Частка життєздатних горішків тут становить 85,2-90,4\%. Підраховано, що в деревостанах щорічно опадає 280-700 тис./га життєздатних горішків липи дрібнолистої, які здатні прорости і сформувати підріст.

Однак, природне насіннєве поновлення липи в деревостанах проходить загалом незадовільно. Це зумовлено несприятливими умовами для проростання горішків і росту самосіву під наметом деревостанів чи навіть на зрубах (Bondar, 2004, Hordienko, \& Karpenko,1996, Hordienko, Hoychuk, \& Hordienko, 1999). Грунтова схожість горішків липи в природних умовах не перевищує 30-40\%, а тих, що потрапили в лісову підстилку, наближається до нуля (Murakhtanov, 1981). В умовах Лісостепу і Полісся України горішки липи починають проростати в кінці травня і навіть на початку червня. В цей період зазвичай встановлюється висока температура повітря, розростається трав'яна рослинність, виникає дефіцит вологи в грунті, а самосів у перші роки після появи росте повільно, що створює несприятливі умови для конкуренції самосіву за чинники середовища (Bondar, 2004, Hordienko, \& Karpenko, 1996). Водночас липа має добру здатність до вегетативного розмноження шляхом формування порості навколо пнів або відводків (Murakhtanov, 1981). На куртинне поновлення липи під наметом деревостанів та інтенсифікацію росту іiі підросту у випадку утворення прогалин вказував також Pigott (1975).

Липа в Україні на $77 \%$ площі, яку вона займає, має природне походження, з яких $58 \%$ деревостанів належать до порослевого і $19 \%$ - до насінного походження. Штучні липові насадження ростуть на площі $23 \%$ (Soshensky, Girs, \& Swynchuk, 2018). Їхню таксаційну структуру та особливості росту липи у різних за складом деревостанах висвітлено в низці робіт (Soshensky, Girs, \& Swynchuk, 2015, 2018, Soshensky, 2015, 2015a, 2016).

Досліджуючи природне поновлення липи дрібнолистої на Поділлі, Bondar (2004) виявив підріст цього деревного виду на $44 \%$ зрубів різного віку, де його кількість коливалася в межах від 4 до 1320 екз./га.

Отже, успішне природне поновлення липи в грабових дібровах розвивається лише на окремих ділянках. Водночас доцільність іiі участі у складі дубових деревостанів різних типів лісу є беззаперечною (Hordienko, \& Karpenko, 1996, Hordienko, Hoychuk, \& Hordienko, 1999). Липа позитивно впливає на ріст і формування дубових деревостанів, а тому актуальним питанням $€$ вивчення шляхів сприяння іï природному поновленню та поширенню в дубових лісостанах Лісостепу.

Об'єкти та методика дослідження. Об 'єктом дослідження слугували лісовідновні процеси в дубових деревостанах різного віку за участю липи дрібнолистої (серцелистої) в умовах свіжої грабової діброви Західного Поділля. Предмет дослідження - кількість підросту деревних видів, їхні фізіологічний стан та інтенсивність росту.

Мета дослідження полягала у встановленні особливостей лісовідновних процесів у дубових деревостанах за різної участі в їхньому складі липи дрібнолистої.

Дослідження проводили в дубових деревостанах за участю липи дрібнолистої. Загалом закладено 22 пробні площі в 41-100-річних лісостанах, де частка липи й дуба у складі деревостанів коливається від поодиноких екземплярів до 10 одиниць. Детальна лісівничо-таксаційна характеристика цих деревостанів наведена у нашій попередній роботі (Zaika, \& Kalenyuk, 2018).

Кількість підросту деревних видів досліджували згідно $з$ прийнятою в лісівництві методикою (Vedmid, Shkudor, \& Buzun, 2008). Для цього на кожній пробній площі закладали по 20 площадок площею по 4 м $^{2}(2 \times 2$ м). На кожній обліковій площадці визначали кількість екземплярів самосіву й підросту, яку розподіляли за деревними видами, фізіологічним станом рослин і групами віку. Підріст за віком поділяли на 1-, 2-3-, 4-8- і 9-15-річки, а за висотою на групи: до 0,25, 0,26-0,50, 0,51-0,75, 0,76-1,00, 1,01-1,50, 1,51-2,00 м. Підріст заввишки до 0,50 м вважали дрібним, 0,51-1,50 м - середнім та 1,51 м і вище - великим. За фізіологічним станом підріст поділяли на здоровий, середньо ослаблений і дуже ослаблений (Vedmid, Shkudor, \& Buzun, 2008).

На 1-5-річних зрубах досліджували природне поновлення липи дрібнолистої. В різних частинах Західного Поділля обстежили по 10 ділянок лісових культур кожної вікової групи (загалом 50 ділянок). На кожній із них здійснили облік кількості екземплярів підросту липи та вимірювання висоти у $15-20$ особин.

Результати дослідження. Лісовий фітоценоз складається із сукупності деревних і кущових видів, які часто істотно відрізняються між собою біологічними властивостями: відношенням до світлового і грунтового живлення, інтенсивністю росту, періодичністю та інтенсивністю плодоношення тощо. Ці властивості зумовлюють здатність видів до природного насіннєвого поновлення та виживання їхнього потомства в конкурентній боротьбі за екологічні чинники. В умовах свіжої грабової діброви Західного Поділля формуються складні мішані деревостани за участю дубів звичайного i червоного, граба звичайного, кленів гостролистого і явора, в'яза голого, ясена звичайного, липи дрібнолистої, берези повислої тощо (Zaika \& Kalenyuk, 2018). Під їхній намет потрапляє близько 1 \% світла, що створює несприятливі умови для формування 
підросту деревних видів. Зазвичай, найуспішніше в таких умовах поновлюються найтіневитриваліші деревні види, до яких належать клен гостролистий, клен-явір, в'яз голий і граб звичайний.

За результатами досліджень, деревні види загалом слабо поновлюються під наметом дубових деревостанів. Нами виявлено від 1,13 до 10,27 тис. екз./га підросту різних деревних видів (табл. 1). У складі підросту трапляються дуби звичайний і червоний, ясен звичайний, клен гостролистий, клен-явір, в'яз голий, граб звичайний, липа дрібнолиста, горобина звичайна і бук лісовий. Низькими показниками природного поновлення характеризуються деревостани на ділянках 6, 7, 8, 9 і 12, де загальна кількість підросту деревних видів становить лише 1,13-2,51 тис. екз./га. На ділянках 5, 16, 17, 18, 19, 20, 21 його кількість перевищує 7 тис. екз./га.

\section{Кількість підросту деревних видів під наметом дослідних лісостанів,}

Таблиия 1 тис. екз./га (2015 рік)

\begin{tabular}{|c|c|c|c|c|c|c|c|c|c|}
\hline \multirow{2}{*}{$\begin{array}{l}\text { № пр. } \\
\text { пл. }\end{array}$} & \multicolumn{2}{|l|}{ Деревостан } & \multirow{2}{*}{$\begin{array}{c}\text { Індекс } \\
\text { деревн. } \\
\text { виду }\end{array}$} & \multicolumn{4}{|c|}{ Вік підросту, років } & \multicolumn{2}{|c|}{ Разом } \\
\hline & склад & вік, років & & 1 & $2-3$ & $4-8$ & $9-15$ & к-сть & $\%$ \\
\hline 1 & 2 & 3 & 4 & 5 & 6 & 7 & 8 & 9 & 10 \\
\hline \multirow{5}{*}{1} & \multirow{5}{*}{ 10Лпд + Бп } & \multirow{5}{*}{45} & Дч & 0,75 & 0,25 & & & 1,00 & 13,8 \\
\hline & & & Кля & 0,50 & 0,50 & 0,38 & 1,00 & 2,38 & 32,8 \\
\hline & & & Бкл & - & 0,63 & 0,13 & - & 0,75 & 10,3 \\
\hline & & & $\Gamma 3$ & - & 0,88 & 1,50 & - & 2,38 & 32,8 \\
\hline & & & Грб & - & & 0,75 & - & 0,75 & 10,3 \\
\hline \multirow{2}{*}{ Всього } & & & & $\underline{1,25}$ & $\underline{2,25}$ & $\underline{2,75}$ & $\underline{1,00}$ & $\underline{5,63}$ & \\
\hline & & & & $\overline{17,2}$ & $\overline{31,0}$ & $\overline{37,9}$ & $\overline{13,8}$ & $\overline{100,0}$ & \\
\hline \multirow{3}{*}{2} & \multirow{3}{*}{$\begin{array}{l}\text { 8Лпд1Мдє1Гз + Дз, } \\
\text { Клг, Чш }\end{array}$} & \multirow{3}{*}{51} & Дз & 0,75 & 0,50 & & - & 1,25 & 30,3 \\
\hline & & & Клг & 0,38 & 0,88 & 0,63 & - & 1,88 & 45,5 \\
\hline & & & $\Gamma 3$ & & 0,63 & 0,38 & - & 1,00 & 24,2 \\
\hline Всього & & & & $\frac{1,13}{27,3}$ & $\frac{2,01}{48,5}$ & $\frac{1,00}{24,2}$ & - & $\frac{4,13}{100,0}$ & \\
\hline \multirow{4}{*}{3} & \multirow{4}{*}{$\begin{array}{l}\text { 6Лпд2Ясз1Дз1Бп + Гз, } \\
\text { Взг, Клг }\end{array}$} & \multirow{4}{*}{45} & Д3 & 0,25 & 0,63 & - & - & 0,88 & 25,0 \\
\hline & & & Клг & 0,63 & 0,63 & - & - & 1,25 & 35,7 \\
\hline & & & Взг & & 0,50 & - & - & 0,50 & 14,3 \\
\hline & & & $\Gamma 3$ & & 0,88 & - & - & 0,88 & 25,0 \\
\hline \multirow[t]{2}{*}{ Всього } & & & & $\frac{0,88}{250}$ & $\frac{2,63}{750}$ & - & - & $\frac{3,50}{1000}$ & \\
\hline & \multirow{5}{*}{$\begin{array}{l}\text { 4Лпд2Ясз2Чш1Дз1Клг } \\
+ \text { Дч, Гз }\end{array}$} & \multirow{5}{*}{55} & & $\frac{25,0}{063}$ & $\begin{array}{l}10,0 \\
075\end{array}$ & - & & $\frac{100,0}{138}$ & \\
\hline \multirow{4}{*}{4} & & & Дч & 0,63 & 0,75 & - & - & 1,38 & 35,5 \\
\hline & & & Яз & 0,75 & & - & - & 0,75 & 19,4 \\
\hline & & & Клг & 0,50 & & - & - & 0,50 & 12,9 \\
\hline & & & $\Gamma 3$ & & 0,63 & - & - & 1,25 & 32,3 \\
\hline \multirow{2}{*}{ Всього } & & & & 1,88 & 1,38 & $\underline{0,63}$ & & $\underline{3,88}$ & \\
\hline & & & & $\overline{48,4}$ & 35,5 & $\overline{16,1}$ & - & $\overline{100,0}$ & \\
\hline \multirow{5}{*}{5} & \multirow{5}{*}{$\begin{array}{l}\text { 4Дз3Клг2Лпд1Бп + Гз, } \\
\text { Кля, Взг }\end{array}$} & \multirow{5}{*}{50} & Д3 & 0,75 & 0,50 & & - & 1,25 & 17,5 \\
\hline & & & Клг & 0,13 & 1,38 & 0,63 & - & 2,13 & 29,5 \\
\hline & & & Кля & 0,25 & 0,38 & 1,00 & - & 1,63 & 22,8 \\
\hline & & & В3г & & 0,13 & 1,13 & - & 1,25 & 17,5 \\
\hline & & & $\Gamma 3$ & & 0,63 & 0,25 & - & 0,88 & 12,3 \\
\hline \multirow{2}{*}{ Всього } & & & & $\underline{1,13}$ & $\underline{3,00}$ & $\underline{3,00}$ & & $\underline{7,14}$ & \\
\hline & & & & 15,8 & 42,1 & 42,1 & & 100,0 & \\
\hline & & & Д3 & 0,25 & 0,13 & & - & 0,38 & 15,0 \\
\hline & & & Лпд & & & 0,88 & - & 0,88 & 35,0 \\
\hline 6 & 5Јпд3Дз2І з + Кля & 56 & Кля & - & 0,50 & & - & 0,50 & 20,0 \\
\hline & & & $\Gamma 3$ & - & 0,13 & 0,63 & - & 0,75 & 30,0 \\
\hline & & & & $\underline{0,25}$ & $\underline{0,76}$ & $\underline{1,50}$ & & 2,51 & \\
\hline Всього & & & & $\overline{10,0}$ & $\overline{30,0}$ & $\overline{60,0}$ & & $\overline{100,0}$ & \\
\hline
\end{tabular}


Продовження таблищі 1

\begin{tabular}{|c|c|c|c|c|c|c|c|c|c|}
\hline 1 & 2 & 3 & 4 & 5 & 6 & 7 & 8 & 9 & 10 \\
\hline \multirow{3}{*}{7} & \multirow{3}{*}{ 4Лпд3Дз2Гз1Чш } & \multirow{3}{*}{56} & Дз & 0,63 & & \multirow{3}{*}{0,88} & - & 0,63 & 35,7 \\
\hline & & & Лпд & & & & \multirow[t]{2}{*}{-} & 0,88 & 50,0 \\
\hline & & & $\Gamma 3$ & & 0,25 & & & 0,25 & 14,3 \\
\hline \multirow[b]{2}{*}{ Всього } & & & & $\underline{0,63}$ & $\underline{0,25}$ & $\underline{0,88}$ & & 1,76 & \\
\hline & & & & $\frac{0,05}{35,7}$ & $\frac{0,20}{14,3}$ & $\frac{0,00}{50,0}$ & & 100,0 & \\
\hline \multirow{3}{*}{8} & \multirow{3}{*}{$\begin{array}{l}\text { 5Дз4Лпд1Гз + Яс3, Клг, } \\
\text { Чш }\end{array}$} & \multirow{3}{*}{55} & Лпд & - & 0,25 & - & - & 0,25 & 22,2 \\
\hline & & & Клг & - & 0,38 & - & - & 0,38 & 33,3 \\
\hline & & & $\Gamma 3$ & - & 0,50 & - & - & 0,50 & 44,5 \\
\hline \multicolumn{2}{|l|}{ Всього } & & & & $\frac{1,13}{100,0}$ & & & $\frac{1,13}{100,0}$ & \\
\hline \multirow{3}{*}{9} & \multirow{3}{*}{ 5Дз4Лпд1Гз } & \multirow{3}{*}{58} & Кля & - & - & 0,25 & & 0,25 & 14,3 \\
\hline & & & Клг & - & - & 0,63 & - & 0,63 & 35,7 \\
\hline & & & $\Gamma 3$ & - & 0,50 & 0,38 & - & 0,88 & 50,0 \\
\hline \multirow{2}{*}{ Всього } & & & & & $\underline{0,50}$ & 1,25 & & 1,76 & \\
\hline & & & & & $\overline{28,6}$ & 71,4 & & $\overline{100,0}$ & \\
\hline \multirow{3}{*}{10} & \multirow{3}{*}{ 5Дз3Лпд1Кля1Гз + Ясз } & \multirow{3}{*}{41} & Яз & 2,13 & 0,63 & - & - & 2,75 & 53,7 \\
\hline & & & Взг & 0,38 & 0,63 & - & - & 1,00 & 19,5 \\
\hline & & & Клг & 0,63 & 0,75 & - & - & 1,38 & 26,8 \\
\hline \multirow[b]{2}{*}{ Всього } & & & & 3,13 & 2,00 & & & 5,13 & \\
\hline & & & & 61,0 & 39,0 & & & 100,0 & \\
\hline \multirow{4}{*}{11} & & & Дз & 1,00 & - & - & - & 1,00 & 22,2 \\
\hline & 3Дз4Гз2Лпд1Ясз + Клг, & 50 & Лпд & - & 0,25 & - & - & 0,25 & 5,6 \\
\hline & & 59 & Клг & - & 0,88 & 0,75 & - & 1,63 & 36,1 \\
\hline & & & $\Gamma 3$ & - & 0,75 & 0,88 & & 1,63 & 36,1 \\
\hline & & & & 1,00 & $\underline{1,88}$ & 1,63 & & 4,50 & \\
\hline Всього & & & & 22,2 & $\overline{41,7}$ & 36,1 & & $\overline{100,0}$ & \\
\hline & & & Дз & 0,88 & - & - & - & 0,88 & 35,0 \\
\hline 12 & 10Дз + Бп & 44 & Кля & - & 0,63 & - & - & 0,63 & 25,0 \\
\hline & & & $\Gamma 3$ & - & - & 1,00 & - & 1,00 & 40,0 \\
\hline & & & & 0,88 & 0,63 & 1,00 & & 2,51 & \\
\hline Всього & & & & 35,0 & $\frac{0,00}{25,0}$ & 40,0 & & 100,0 & \\
\hline & & & Дз & 1,25 & - & - & - & 1,25 & 32,3 \\
\hline 13 & 9Дз1Ос + Лпд, Гз, Чш & 55 & Лпд & - & 0,63 & - & - & 0,63 & 16,1 \\
\hline & & & $\Gamma 3$ & - & 0,88 & 1,13 & - & 2,00 & 51,6 \\
\hline Poroso & & & & 1,25 & 1,50 & 1,13 & & 3,88 & \\
\hline Всього & & & & $\overline{32,3}$ & $\overline{38,7}$ & 29,0 & & $\overline{100,0}$ & \\
\hline & & & Д3 & 0,75 & - & - & - & 0,75 & 11,3 \\
\hline & 5Дз2Лпд1Клг1Гз & & Кля & 0,25 & 0,75 & 1,50 & - & 2,50 & 37,7 \\
\hline 14 & 1 Взг + Бп, Чш & 63 & Взг & - & 1,00 & 1,50 & - & 2,50 & 37,7 \\
\hline & & & $\Gamma 3$ & 0,25 & 0,63 & - & - & 0,88 & 13,2 \\
\hline & & & & $\underline{1,25}$ & $\underline{2,38}$ & $\underline{3,00}$ & & $\underline{6,63}$ & \\
\hline Всього & & & & 18,9 & 35,8 & 45,3 & - & $\overline{100,0}$ & \\
\hline & & & Д3 & 1,63 & 0,50 & - & - & 2,13 & 32,7 \\
\hline 15 & 6Дз3Лпд1Гз + Oc & 75 & Лпд & - & 0,75 & 0,63 & - & 1,38 & 21,2 \\
\hline & & & Гз & - & 1,25 & 1,75 & - & 3,00 & 46,2 \\
\hline & & & & 1,63 & 2,50 & 2,38 & & $\underline{6,51}$ & \\
\hline Всього & & & & 25,0 & 38,5 & 36,5 & - & 100,0 & \\
\hline & & & Дз & 0,75 & 0,63 & - & - & 1,38 & 17,7 \\
\hline & 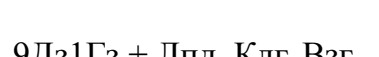 & 64 & Клг & 0,63 & 1,00 & 1,25 & - & 2,88 & 37,1 \\
\hline 16 & 9Дз1Пз + Лпд, Клг, Взг & 64 & Взг & - & 0,25 & 1,25 & - & 1,50 & 19,4 \\
\hline & & & $\Gamma 3$ & - & 0,50 & 1,50 & - & 2,00 & 25,8 \\
\hline
\end{tabular}


Продовження таблиці 1

\begin{tabular}{|c|c|c|c|c|c|c|c|c|c|}
\hline 1 & 2 & 3 & 4 & 5 & 6 & 7 & 8 & 9 & 10 \\
\hline Всьогс & & & & $\frac{1,38}{17,7}$ & $\frac{2,38}{30,6}$ & $\frac{4,00}{51,6}$ & - & $\frac{7,76}{100,0}$ & \\
\hline \multirow{5}{*}{17} & \multirow{5}{*}{$\begin{array}{l}\frac{10 Д 3}{6 Г з 2 Л п д 1 К л г 1 Ч ш ~+~} \\
\text { Кля, Бкл, Взг }\end{array}$} & \multirow{5}{*}{77} & Дз & 1,50 & 0,88 & - & - & 2,38 & 26,4 \\
\hline & & & Клг & - & 0,50 & 1,13 & - & 1,63 & 18,1 \\
\hline & & & Кля & 1,50 & 0,38 & 0,75 & - & 2,63 & 29,2 \\
\hline & & & Бкл & 0,50 & 0,25 & - & - & 0,75 & 8,3 \\
\hline & & & Взг & - & 0,50 & 1,13 & - & 1,63 & 18,1 \\
\hline \multicolumn{2}{|c|}{ Всього } & & & $\underline{3,50}$ & $\frac{2,50}{27,8}$ & $\underline{3,00}$ & - & $\frac{9,02}{100,0}$ & \\
\hline \multirow{4}{*}{18} & \multirow{4}{*}{ 6Лпд2Д32Гз } & \multirow{4}{*}{100} & Дз & 1,00 & 0,75 & 0,88 & - & 2,63 & 34,4 \\
\hline & & & Лпд & - & - & 0,88 & - & 0,88 & 11,5 \\
\hline & & & В3г & - & 0,38 & 0,38 & 0,38 & 1,14 & 14,8 \\
\hline & & & Гз & - & 0,50 & 1,50 & 1,00 & 3,00 & 39,3 \\
\hline \multirow{2}{*}{\multicolumn{2}{|c|}{ Всього }} & & & 1,00 & 1,63 & $\underline{3,63}$ & 1,38 & 7,65 & \\
\hline & & & & 13,1 & 21,3 & 47,5 & 18,0 & 100,0 & \\
\hline \multirow{4}{*}{19} & \multirow{4}{*}{ 5Дз3Лпд2Гз + Клг } & \multirow{4}{*}{90} & Дз & 1,38 & 0,63 & - & - & 2,00 & 21,3 \\
\hline & & & Лпд & - & - & 0,88 & - & 0,88 & 9,3 \\
\hline & & & Клг & 0,25 & 0,75 & 1,13 & 0,75 & 2,88 & 30,7 \\
\hline & & & Гз & - & 1,25 & 1,38 & 1,00 & 3,63 & 38,7 \\
\hline \multicolumn{2}{|c|}{ Всього } & & & $\frac{1,63}{17,3}$ & $\frac{2,63}{28,0}$ & $\frac{3,38}{36,0}$ & $\frac{1,75}{18,7}$ & $\frac{9,38}{100,0}$ & \\
\hline \multirow{5}{*}{20} & \multirow{5}{*}{$\begin{array}{l}\text { 2Дз5Гз2Лпд1 Ясз + Клг, } \\
\text { Взг }\end{array}$} & \multirow{5}{*}{92} & Дз & 2,00 & 0,88 & 0,25 & - & 3,13 & 30,5 \\
\hline & & & Лпд & - & - & 1,13 & - & 1,13 & 11,0 \\
\hline & & & Яз & 1,13 & 1,13 & 0,63 & - & 2,88 & 28,0 \\
\hline & & & Клг & - & 1,13 & 0,88 & - & 2,00 & 19,5 \\
\hline & & & В3г & - & 0,38 & 0,75 & - & 1,13 & 11,0 \\
\hline \multicolumn{2}{|c|}{ Всього } & & & $\frac{3,13}{30,5}$ & $\frac{3,50}{34,1}$ & $\frac{3,63}{35,4}$ & - & $\frac{10,27}{100,0}$ & \\
\hline \multirow{4}{*}{21} & \multirow{4}{*}{ 5Дз3Гз2Лпд } & \multirow{4}{*}{96} & Дз & 1,00 & 0,38 & - & - & 1,38 & 16,4 \\
\hline & & & Лпд & - & - & 0,63 & - & 0,63 & 7,5 \\
\hline & & & Взг & - & 0,75 & 1,50 & 0,88 & 3,13 & 37,3 \\
\hline & & & $\Gamma 3$ & - & 1,38 & 1,25 & 0,63 & 3,25 & 38,8 \\
\hline \multirow{2}{*}{\multicolumn{2}{|c|}{ Всього }} & & & 1,00 & 2,50 & $\underline{3,38}$ & 1,50 & $\underline{8,39}$ & \\
\hline & & & & 11,9 & 29,9 & 40,3 & 17,9 & 100,0 & \\
\hline \multirow{4}{*}{22} & \multirow{4}{*}{ 9Дз1Гз + Лпд, Ясз } & \multirow{4}{*}{89} & Дз & 1,63 & 0,88 & - & - & 2,50 & 37,0 \\
\hline & & & Лпд & - & 0,50 & 0,88 & - & 1,38 & 20,4 \\
\hline & & & Яз & 0,88 & 1,00 & - & - & 1,88 & 27,8 \\
\hline & & & $\Gamma 3$ & - & - & 1,00 & - & 1,00 & 14,8 \\
\hline \multicolumn{4}{|c|}{ Всього } & $\frac{2,50}{37,0}$ & $\frac{2,38}{35,2}$ & $\frac{1,88}{27,8}$ & - & $\frac{6,75}{100,0}$ & \\
\hline
\end{tabular}

Примітки: Дз - дуб звичайний, Клг - клен гостролистий, Кля - клен-явір, Лпд - липа дрібнолиста (серцелиста), Взг - в'яз голий, Гз - граб звичайний, Дч - дуб червоний, Грб - горобина звичайна, Бкл - бук лісовий; Ясз - ясен звичайний.

У чисельнику - абсолютні значення (тис. екз./га), в знаменнику - відносні (\%).

За віковою структурою на переважній кількості ділянок домінує 1-3-річний підріст. У $59 \%$ деревостанів його частка становить 50-100\%, а на інших коливається в межах 28,6-48,4\%. Найбільшу частку 1-3-річного підросту деревних видів (понад 75\%) виявлено в деревостанах на пробних площах 2,4 , 10 , де він на $30 \%$ і більше представлений дубами звичайним і червоним, ясенем звичайним.
Підріст старшого віку під наметом деревостанів трапляється дуже зрідка. Вікові групи 4-8 років i більше восьми років сформовані підростом кленів гостролистого та явора, в'яза і граба. Необхідно зазначити, що 9-15-річний підріст трапляється тільки на окремих ділянках (пр. пл. 1, 18, 19, 21) iз часткою $13,8-18,7 \%$, а 4-8-річний не виявлений тільки в двох деревостанах (пр. пл. 3 і 10). На ін- 
ших ділянках його частка коливається в межах $16,1-71,4 \%$.

Отримані результати показують, що на появу i формування підросту деревних видів під наметом деревостанів впливає сукупність чинників, які, своєю чергою, впливають на видові біологічні особливості плодоношення, умови проростання насінин та виживання і ріст молодого покоління деревних видів. Особливе значення тут відіграє кількість підросту тіневитривалих видів.

Нами здійснене дослідження кореляційних зв'язків між загальною кількістю підросту і таксаційними показниками материнських деревостанів. Так, величина кореляційного зв'язку (r) кількості підросту з густотою деревостанів становить $-0,13$, 3 середнім діаметром -0,35, 3 середньою висотою $-0,26$ і з абсолютною повнотою -0,31. Множинний коефіцієнт кореляції залежності кількості підросту від таксаційних показників деревостанів становить $0,47$.

Серед деревних видів найкраще поновлюються клен гостролистий, клен-явір, граб звичайний і в’яз голий. Підріст цих деревних видів добре виживає i росте під наметом материнських деревостанів в умовах недостатнього освітлення. Ці види формують підріст 4-8-річного віку і старший.
Дуб звичайний характеризується переважно незадовільним плодоношенням. Очевидно, сприятливі для плодоношення роки у цього деревного виду в умовах Західного Поділля повторюються доволі зрідка. Нами виявлено підріст дуба 1-3-річного віку на 72,3\% ділянок, де його кількість становила в межах 0,25-2,63 тис. екз./га. У двох деревостанах (пр. пл. 18 і 20) виявлено 0,25-0,88 тис. екз./га підросту дуба звичайного вікової групи 4-8 років, який приурочений до розріджених ділянках деревостанів.

Ще гірше поновлюється липа дрібнолиста. Її підріст насіннєвого походження виявлено на 45,5 \% дослідних деревостанів у кількості 0,25-1,38 тис. екз./ га 3 участю у видовому складі природного поновлення 5,6-35,0\%. Незалежно від умов для проростання насіння та інтенсивності плодоношення липи дрібнолистої, вид характеризується незадовільним насіннєвим поновленням. Цей факт відзначено також іншими дослідниками (Hordienko, \& Karpenko, 1996, Murakhtanov, 1981, Hordienko, Hoychuk, \& Hordienko, 1999). Їі життєздатне насіння незадовільно проростає у лісовій підстилці, а підріст поступається в конкуренції клену гостролистому, клену-явору і в’язу гладкому.

На дослідних ділянках відзначено значну варіабельність підросту деревних видів за висотою (табл. 2).

Табличяя 2

Загальний розподіл підросту деревних видів за висотою, \%

\begin{tabular}{|c|c|c|c|c|c|c|}
\hline \multirow{2}{*}{$\begin{array}{c}\text { № пр. } \\
\text { пЛ. }\end{array}$} & \multicolumn{6}{|c|}{ Висотні групи підросту, м } \\
\hline & до 0,25 & $0,26-0,50$ & $0,51-0,75$ & $0,76-1,00$ & $1,01-1,50$ & $1,51-2,00$ \\
\hline 1 & 43,4 & 25,5 & 21,1 & 7,2 & 2,8 & - \\
\hline 2 & 72,8 & 16,8 & 10,4 & - & - & - \\
\hline 3 & 93,8 & 6,2 & - & - & - & - \\
\hline 4 & 88,5 & 8,2 & 2,8 & 0,5 & - & - \\
\hline 5 & 82,6 & 15,5 & 1,9 & - & - & - \\
\hline 6 & 60,3 & 10,1 & 6,7 & 22,9 & - & - \\
\hline 7 & 45,6 & 4,4 & 28,5 & 21,6 & - & - \\
\hline 8 & 65,6 & 30,3 & 4,1 & - & - & - \\
\hline 9 & 46,0 & 44,5 & 8,3 & 1,2 & - & - \\
\hline 10 & 97,9 & 2,1 & - & - & - & - \\
\hline 11 & 33,6 & 24,0 & 20,5 & 16,6 & 5,3 & - \\
\hline 12 & 63,8 & 20,4 & 15,8 & - & - & - \\
\hline 13 & 54,0 & 22,9 & 15,2 & 7,9 & - & - \\
\hline 14 & 42,0 & 34,8 & 19,3 & 3,8 & - & - \\
\hline 15 & 63,7 & 32,4 & 3,2 & 0,7 & - & - \\
\hline 16 & 70,0 & 27,3 & 2,6 & - & - & - \\
\hline 17 & 71,0 & 28,0 & 1,0 & - & - & - \\
\hline 18 & 53,9 & 19,4 & 20,4 & 3,3 & 2,3 & 0,7 \\
\hline 19 & 47,1 & 19,3 & 18,5 & 10,9 & 4,2 & - \\
\hline 20 & 79,7 & 10,4 & 6,0 & 3,5 & 0,4 & - \\
\hline 21 & 49,8 & 29,1 & 19,6 & 1,5 & - & - \\
\hline 22 & 68,4 & 18,1 & 13,2 & 0,3 & - & - \\
\hline
\end{tabular}


Кількість дрібного підросту заввишки до 50 см на різних ділянках коливається в межах від 50 до $100 \%$. Лише в окремих деревостанах (пр. пл. 1, $7,11,19)$ кількість дрібного підросту виявилась в межах 50-69\%. У переважної кількості деревостанів частка дрібного підросту перевищує $80 \%$. Кількість середнього підросту змінюється в дуже широких межах - від повної відсутності до $50 \%$. Необхідно виділити низку деревостанів (пр. пл. 1, $6,7,11,13,14,19,21)$, де частка середнього підросту перевищує $20 \%$. Незначна кількість $(0,7 \%)$ великого підросту виявлена лише на ділянці 18.

Серед деревних видів весь підріст дубів звичайного і червоного, ясена звичайного, бука лісового відноситься до дрібного, заввишки не більше $25 \mathrm{~cm}$. На ділянках 3 і 10 трапляється тільки дрібний підріст різних деревних видів.

Несприятливі умови для росту підросту окремих деревних видів склались і на деяких інших ділянках. Так, у низці деревостанів (пр. пл. 4, 5, 20) трапляється лише дрібний підріст клена гостролистого, граба звичайного (пр. пл. 8 і 14), в'яза голого (пр. пл. 20), клена-явора (пр. пл. 12), липи дрібнолистої (пр. пл. 13). Помірний кореляційний зв'язок встановлено між густотою деревостанів і часткою дрібного $(\mathrm{r}=0,33)$ та середнього $(\mathrm{r}=-0,33)$ підросту. Спостерігається зростання залежності висоти підросту де- ревних видів від густоти деревостанів. Зі збільшенням густоти материнських деревостанів кількість середнього за висотою підросту зменшується. Така залежність зумовлена відпадом підросту світлолюбних видів та пригніченням росту тіневитривалих.

Материнський деревостан істотно впливає не лише на ріст, але й на фізіологічний стан підросту деревних видів (табл. 3).

Отже, в досліджених деревостанах переважає середньо ослаблений підріст деревних видів, частка якого становить 41,1-54,1\%. Поряд із цим, значною мірою представлений дуже ослаблений підріст (19,1-41,8\%). Частка здорового підросту в деревостанах коливається в межах 14,0-30,5\%. Серед деревних видів найгіршим станом характеризується підріст дуба звичайного, дуба червоного i ясена звичайного. На переважній кількості ділянок частка дуже ослабленого підросту цих видів змінюється в межах 30-60\%, а здорового - від 3,8 до $18,7 \%$.

Трапляння підросту деревних видів у деревостанах становить 30-95\% (див. табл. 3). Низьким показниками трапляння характеризується підріст на ділянках $4,6,7,8,9,12$, де його частка становить $30-50 \%$. Серед деревних видів найнижчим показником трапляння характеризується підріст липи дрібнолистої.

Табличя 3

Трапляння підросту деревних видів та його фізіологічний стан, \%

\begin{tabular}{ccccc}
\hline \multirow{2}{*}{ № пр. пл. } & \multicolumn{3}{c}{ Стан підросту } & \multirow{2}{*}{ Траплянн, \% } \\
\cline { 2 - 4 } 1 & здоровий & середньо ослаблений & дуже ослаблений & 90 \\
2 & 16,2 & 53,7 & 30,1 & 65 \\
3 & 14,8 & 45,0 & 40,2 & 65 \\
4 & 17,4 & 45,4 & 37,2 & 50 \\
5 & 17,2 & 41,1 & 41,7 & 80 \\
6 & 20,9 & 46,2 & 32,9 & 40 \\
7 & 18,4 & 45,2 & 36,4 & 40 \\
8 & 14,9 & 48,8 & 36,3 & 30 \\
9 & 18,9 & 47,9 & 33,2 & 35 \\
10 & 28,0 & 47,7 & 24,3 & 75 \\
11 & 14,0 & 49,5 & 36,5 & 75 \\
12 & 18,2 & 54,0 & 27,8 & 50 \\
13 & 22,4 & 51,9 & 25,7 & 70 \\
14 & 23,8 & 43,2 & 33,0 & 75 \\
15 & 27,3 & 51,7 & 21,0 & 80 \\
16 & 26,0 & 48,9 & 25,1 & 90 \\
17 & 30,5 & 50,4 & 19,1 & 90 \\
18 & 23,1 & 50,0 & 26,9 & 85 \\
19 & 26,0 & 51,6 & 22,4 & 80 \\
20 & 22,9 & 50,8 & 26,3 & 85 \\
21 & 21,1 & 49,7 & 29,2 & 80 \\
22 & 28,7 & 48,9 & 22,4 & \\
\hline
\end{tabular}


Незадовільне природне насінне поновлення липи дрібнолистої виявлено також на зрубах (табл. 4).

Нами виявлено природне насіннєве поновлення липи дрібнолистої на $38 \%$ зрубів. На однорічних зрубах підріст липи трапляється на $50 \%$ ділянок, на 2- і 3-річних - на 40\% і на 4-5-річних - на $30 \%$. Його кількість коливається в межах 55-275 екз./га. Встановлено певні закономірності зміни кількості підросту липи із збільшенням віку зрубів. Так, на однорічних зрубах середнє значення кількості підросту липи становить 154 екз./га. На 2-3-річних зрубах його кількість зростає до 214-248, а на 5-річних - знижується до 89 екз./га. Очевидно, що із збільшенням віку зрубів кількість підросту липи на них буде зменшуватись у зв'язку з відпадом внаслідок конкуренції з боку трав'яної рослинності. На ділянках лісових культур міжряддя в умовах грабових дібров інтенсивно заростають трав'яною рослинністю, а догляд здійснюють тільки в рядах (рис.).

\section{Кількість самосіву та підросту (екз./га) липи дрібнолистої на зрубах Західного Поділля}

Таблиия 4

\begin{tabular}{ccccccccc}
\hline $\begin{array}{c}\text { Вік } \\
\text { зрубів, } \\
\text { роки }\end{array}$ & \multicolumn{3}{c}{ Номери ділянок } \\
\cline { 2 - 9 } & 1 & 2 & 3 & 4 & 5 & екз./га & h, см & V, \% \\
\hline 1 & 165 & 179 & 124 & 143 & 161 & 154 & $13,2 \pm 0,6$ & 14,4 \\
2 & 205 & 150 & 220 & 185 & - & 214 & $19,9 \pm 1,1$ & 22,1 \\
3 & 251 & 275 & 189 & 248 & - & 248 & $26,7 \pm 1,4$ & 26,8 \\
4 & 167 & 278 & 125 & - & - & 190 & $32,6 \pm 1,8$ & 27,6 \\
5 & 88 & 125 & 55 & - & - & 89 & $40,6 \pm 2,2$ & 31,7 \\
\hline
\end{tabular}

Примітка. Коефіцієнт варіації стосується висоти підросту

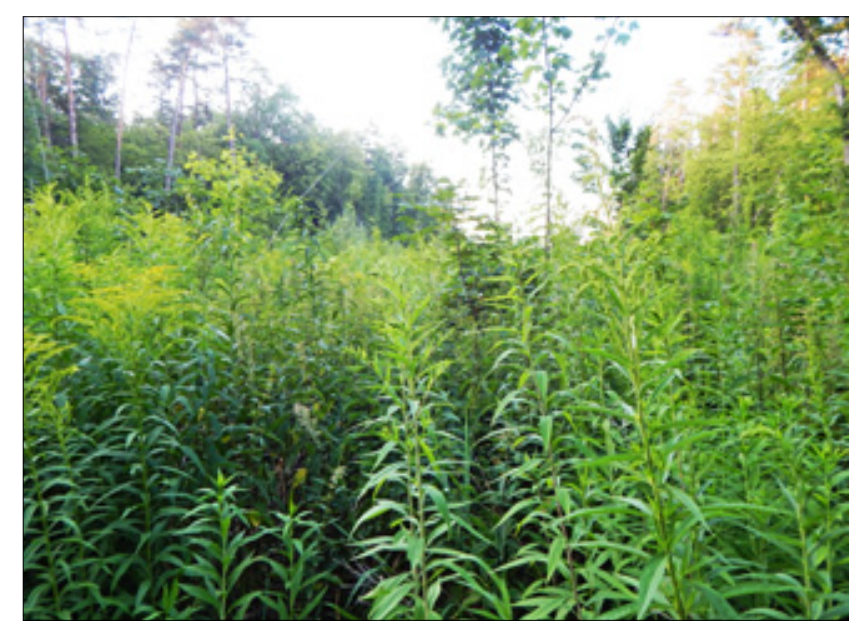

Рис. Загальний вигляд 5-річного зруба в умовах свіжої грабової діброви

Середня висота підросту липи збільшується 3 віком - від 13,2 см на 1-річних до 40,6 см - на 5-річних зрубах. Підріст липи на зрубах зазвичай $\epsilon$ попереднім і на 1-2 роки старшим, ніж вік самих зрубів. У зв'язку з цим, варіабельність висоти підросту липи на зрубах збільшується з їх віком від 14,4 (1-річний) до 31,7\% (5-річний). На збільшення варіабельності висоти підросту липи тут впливає трав'яна рослинність, яка інтенсивно розвивається на зрубах.

Незадовільне насіннєве поновлення липи дрібнолистої на зрубах пояснюється біологічною особливістю її горішків, які мають глибокий насінний спокій, умовами їх проростання і росту самого самосіву. Загалом горішки липи характеризуються високими показниками життєздатності (табл. 5).
Життєздатність горішків липи в різні роки спостереження залишається переважно високою і коливається від 55 до $94 \%$. Найнижчі їі показники (55\%) спостережено в 2017 р. в Улашківському і в 2015 р. у Дорогичівському лісництвах. Переважаючою $\epsilon$ життєздатність у межах 85-94\%. Зважаючи на те, що липа дрібнолиста переважно щорічно рясно цвіте $\mathrm{i}$ плодоносить, а її горішки характеризуються високою життєздатністю, потенційно можна очікувати іiі високий лісовідновний потенціал. Однак, у лісових фітоценозах і на зрубах підріст липи дрібнолистої відсутній або наявний у незначній кількості.

Незважаючи на незадовільне природне поновлення липи дрібнолистої, іiі розведенню в регіоні дослідження приділяється недостатньо уваги. Загалом у лісгоспах західно-подільського регіону щорічна заготівля насіння липи коливається в межах 0,5-14,0 кг, з якого вирощують 0,9-12,1 тис. сіянців (табл. 6).

За щорічної заготівлі горішків липи дрібнолистої в окремі роки садивний матеріал деревного виду не вирощують взагалі. Лісові культури за участю липи дрібнолистої впродовж досліджуваного періоду створені на площі 1,9-15,2 га за незначної участі iii екземплярів у складі штучного насадження (6080 шт./га). На нашу думку, для успішного формування деревостанів з часткою липи 1-2 од. в лісові культури необхідно вводити 200-300 екз./га цісї породи.

Висновки. Природне поновлення в деревостанах свіжої грабової діброви Західного Поділля є переважно незадовільним. Загальна кількість підросту деревних видів коливається в межах від 1,13 до 10,27 тис. екз./га. У його складі трапляються дуби звичайний і червоний, ясен звичайний, клен гостролистий, клен-явір, в'яз голий, граб звичайний, 
Посівні якості горішків липи дрібнолистої в деревостанах Західного Поділля

\begin{tabular}{lllcc}
\hline \multicolumn{1}{c}{$\begin{array}{c}\text { Державне } \\
\text { підприємство }\end{array}$} & \multicolumn{1}{c}{ Лісництво } & Рік & $\begin{array}{c}\text { Життєздатність } \\
\text { горішків, \% }\end{array}$ & Клас якості \\
\hline Кременецьке & Суразьке & 2013 & 91 & 1 \\
Кременецьке & Суразьке & 2014 & 89 & 1 \\
Бучацьке & Дорогичівське & 2015 & 55 & 3 \\
Кременецьке & Суразьке & 2015 & 86 & 1 \\
Тернопільське & Золозецьке & 2015 & 94 & 1 \\
Бережанське & Бережанське & 2016 & 89 & 1 \\
Бучацьке & Золотопотіцьке & 2016 & 70 & 2 \\
Кременецьке & Суразьке & 2016 & 89 & 1 \\
Чортківське & Улашівське & 2016 & 85 & 1 \\
Чортківське & Улашівське & 2017 & 55 & 3 \\
\hline
\end{tabular}

Примітка. Показники схожості наведені за даними ВП «Львівська лісонасіннєва лабораторія»

Обсяги заготівлі насіння, вирощування сіянців і створення лісових культур

Таблиия 6 за участю липи дрібнолистої

\begin{tabular}{ccccc}
\hline Рік & $\begin{array}{c}\text { Заготовлено } \\
\text { горішків, кг }\end{array}$ & $\begin{array}{c}\text { Вирощено сіянців, } \\
\text { тис. шт. }\end{array}$ & $\begin{array}{c}\text { Створено лісових } \\
\text { культур, га }\end{array}$ & $\begin{array}{c}\text { Кількість сіянців липи в } \\
\text { культурах, шт. / га }\end{array}$ \\
\hline 2012 & & ДП «Кременецьке лісове господарство» & - \\
2011 & 13,0 & 3,1 & - & - \\
2010 & 14,0 & 2,5 & - & - \\
2009 & 8,0 & - & - & - \\
2008 & 5,0 & 0,9 & - & 80 \\
\hline & 4,4 & 4,2 & 12,6 & - \\
\hline 2012 & & ДП «Тернопільське лісове господарство» & - \\
2011 & 2,3 & 3,0 & - & 80 \\
2010 & 2,0 & 9,9 & 10,4 & 60 \\
2009 & 2,5 & - & - & - \\
2008 & 5,3 & 8,2 & 9,3 & - \\
\hline 2012 & 6 & 12,1 & 15,2 & - \\
2011 & & ДП «Чортківське лісове господарство» & - \\
2010 & 2,9 & 2,3 & - & 60 \\
2009 & 6,0 & - & - & - \\
2008 & 0,5 & 1,7 & - & \\
\hline
\end{tabular}

липа дрібнолиста, горобина звичайна, бук лісовий. У віковій структурі на більшості ділянок домінує 1-3-річний підріст. У $59 \%$ досліджених деревостанів його частка становить $50-100 \%$, а на інших коливається в межах 28,6-48,4\%. Серед деревних видів найкраще поновлюються клен гостролистий і клен-явір, граб звичайний та в'яз голий, підріст яких під наметом материнських деревостанів досягає 4-8-річного віку і більше. Підріст дуба 1-3-річного віку виявлено на 72,3 \% ділянок, де його кількість становить 0,25-2,63 тис. шт./га. Підріст липи насіннєвого походження трапляється в $45,5 \%$ до- слідних деревостанів в кількості 0,25-1,38 тис. шт./га 3 участю 5,6-35,0\% від загальної кількості природного поновлення. Кількість дрібного підросту на різних ділянках коливається в межах від 50 до $100 \%$. У деревостанах переважає середньо ослаблений (41,1-54,1\%) та значною мірою представлений дуже ослаблений (19,1-41,8\%) підріст деревних видів. Частка здорового підросту в деревостанах коливається в межах $14,0-30,5 \%$. Трапляння підросту в деревостанах становить 30-95\%. Серед деревних видів найнижчими показниками трапляння характеризується підріст липи дрібнолистої. 
Природне насіннєве поновлення липи дрібнолистої виявлено на $38 \%$ від загальної кількості обстежених 1-5-річних зрубів. Його кількість змінюється в межах 55-275 шт./га. Середня висота підросту липи збільшується 3 віком - від 13,2 см на 1-річних, до 40,6 см на 5-річних зрубах. Життєздатність горішків липи в різні роки досліджень залишається переважно високою (55-94\%).

На зрубах після створення лісових культур для збереження підросту липи необхідно здійснювати агротехнічні догляди не лише в рядах, але й в міжряддях. На ділянках за відсутності або незначної кількості підросту липи необхідно вводити її в лісові культури в кількості 200-300 шт./га. В умовах грабових дібров Західного Поділля під час формування деревостанів необхідно забезпечити частку липи в їхньому складі в кількості 1-2 одиниці.

\section{Бібліографічні посилання}

Bondar, A. O. (2004). Renewal of tree plants on the logging areas. Scientific Bulletin of the Ukrainian State Forestry University, 14.6, 154-165 (in Ukrainian).

Vedmid, M. M., Shkudor, V.D., \& Buzun, V. O. (2008). Regenerarion of natural forest stands of the West Polissya. Zhytomyr: Polissya (in Ukrainian).

Hordienko, M.I., \& Karpenko, I.V. (1996). Smallleaved lime and the lime-involving plantations. Kyiv: Agriculture (in Ukrainian).

Hordienko, M.I., Hoychuk, A. F., \& Hordienko, N. M. (1999). Artificial forests in fertile oak forest types. Zhytomyr: Polissya (in Ukrainian).

Zaika, V. K., \& Kalenyuk, Yu.S. (2018). Growth and formation of oak forest stands with the participation of small-leaved lime under conditions of fresh hornbeam-oak forests of the West Podillya. Scientific works of the Forestry Academy of Sciences of Ukraine, 17, 37-45. https://doi.org/10.15421/411818 (in Ukrainian).

Murakhtanov, E. S. (1981). Limespecies. Moscow: Forestry (in Russian).

Pigott, C.D. (1975). Natural regeneration of Tilia cordata in relation to forest structure in the forests of Bialowieza, Poland. Biological sciences, 270 (904), 151-179.

Soshensky, O.M., Girs, O.A., \& Swynchuk, V.A. (2015). Analysis of productivity of lime stands in Ukraine [Electronic resource]. Scientific reports of National University of Life and Environmental Sciences of Ukraine, 3, 1-11. - Retrieved from: http:// nbuv.gov.ua /UJRN/Nd_2015_3_22 (in Ukrainian).

Soshensky, O.M. (2015). Size-quality structure of lime tree trunks in young- and middle-aged stands. Scientific Bulletin of National University of Life and Environmental Sciences of Ukraine. - Series of forestry and ornamental gardening, 229, 31-38 (in Ukrainian).

Soshensky, O. M. (2015a). Development of standards for determining the growing stock and size-quality structure of mature lime stands. Scientific Bulletin of Ukrainian National Forestry University, 25.9, 82-89 (in Ukrainian).

Soshensky, O. M. (2016). Mensurational description of lime stand structure by diameter. Scientific Bulletin of Ukrainian National Forestry University, 26.3, 164171 (in Ukrainian).

Soshensky, O., Girs, O., \& Swynchuk, V. (2018). Measurements of trees and trees of linden heart disease. Kyiv: CPP «Comprint» (in Ukrainian).

\section{Лесовосстановительные процессы в дубовых древостоях с участием липы мелколистной в условиях Западного Подолья}

\section{В. К. Заика', Ю.С. Каленюк²}

Исследованы лесовосстановительные процессы в 41-100-летних дубовых древостоях с участием липы мелколистной и на вырубках 1-5-летнего возраста в условиях свежей грабовой дубравы Западного Подолья. Долевое участие дуба и липы в их составе колеблется от единичных деревьев до 10 единиц. Исследование количества подроста древесных видов проводили путем закладки на каждом участке по 20 пробных участков площадью 4 м $^{2}$ каждый $(2 \times 2$ м). На них определяли количество самосева и подроста, который распределяли по древесным видам, физиологическому состоянию и группам возраста. Подрост высотой до 0,50 м считался мелким, 0,51-1,50 м средним, 1,51 м и выше - крупным. По физиологическому состоянию подрост разделяли на здоровый, средне ослабленный и очень ослабленный. Установлено, что естественное возобновление в древостоях проходит преимущественно неудовлетворительно. Общее количество подроста древесных видов колеблется в пределах от 1,13 до 10,27 тыс. экз./га. В его видовом составе встречаются дуб черешчатый и красный, ясень обыкновенный, клен остролистный, клен-явор, вяз голый, граб обыкновенный, липа мелколистная, рябина обыкновенная, бук лесной. Выявлено, что в возрастной структуре на подавляющем количестве опытных участков доминирует $1-3$-летний подрост. В $59 \%$ древостоев его участие составляет $50-100 \%$, а в других колеблется в пределах 28,6-48,4\%. Среди древесных видов лучше всего возобновляются клен остролистный, клен-явор,

Заика Владимир Константинович - академик Лесной академии наук Украины, доктор биологических наук, профессор кафедры лесоводства. Национальный лесотехнический университет Украины, ул. генерала Чупринки, 103, г. Львов, 79057, Украина. Тел.: 032-258-42-80, +38-067-148-06-26. E-mail: vkzaika@ukr.net ORCID: https://orcid.org/0000-0002-6784-023

Каленюк Юрий Степанович - преподаватель, Кременецкий лесотехнический колледж, ул. Молодежная 1 , с. Белокриница Тернопольской обл., 47014, Украина. Тел.: 035-46-52-404; +38096-367-15-16. E-mail: kaleniukyurii@gmail.com 
граб обыкновенный, вяз голый, подрост которых под пологом материнских древостоев достигает 4-8-летнего возраста и старше. Подрост дуба 1-3-летнего возраста выявлен на 72,3\% участков, где его количество составляет 0,25-2,63 тыс. экз./га. Подрост липы семенного происхождения встречается в 45,5\% экспериментальных древостоев в количестве 0,25-1,38 тыс. экз./га с долевым участием 5,6-35,0\%. Встречаемость подроста в древостоях составляет 30-95\%. Среди древесных видов низкими показателями встречаемости характеризуется подрост липы мелколистной. Долевое участие мелкого подроста на разных участках колеблется в пределах от 50 до $100 \%$. Среди древесных видов весь подрост дуба черешчатого и красного, ясеня обыкновенного и бука лесного относится к мелкому, высота которого обычно не превышает 25 см. В древостоях преобладает среднеослабленный $(41,1-54,1 \%)$ и значительно представлен очень ослабленный (19,1-41,8\%) подрост древесных видов. Долевое участие здорового подроста в древостоях колеблется в пределах $14,0-30,5 \%$. Естественное семенное возобновление липы мелколистной выявлено на $38 \%$ от числа обследованных 1-5-летних вырубок. На однолетних вырубках подрост липы встречается на $50 \%$ участков, на 2 и 3-летних - на 40\% и на 4-5-летних - на $30 \%$. Его количество колеблется в пределах 55275 экз./га. Средняя высота подроста липы увеличивается с возрастом - от 13,2 см на 1-летних до 40,6 см на 5-летних вырубках. Жизнеспособность орешков липы в разные годы исследований остается преимущественно высокой и колеблется в пределах $55-94 \%$.

Ключевые слова: самосев; подрост; жизнеспособность орешков; встречаемость; физиологическое состояние; видовой состав.

\section{Forest regeneration processes in oak stands with the participation of small-leaved lime under the conditions of the West Podillya}

\author{
V. Zaika' ${ }^{1}$ Yu. Kalenuk ${ }^{2}$
}

The forest regeneration processes were investigated in the 41-100-year-old oak stands with the participation of small-leaved lime and on the 1-5-year-old harvesting areas under conditions of fresh hornbeam-oak forests

Volodymyr Zaika - full Member of the Forestry Academy of Sciences of Ukraine, Doctor of Biological Sciences, Professor of the Department of Forestry. Ukrainian National Forestry University. 103, General Chuprynka st., 103, Lviv, 79057, Ukraine. Tel.: 032-258-42-80, +38-067-148-06-26. E-mail: vkzaika@ukr. net ORCID: https://orcid.org/0000-0002-6784-023

Yurii Kalenuk - Lecturer, Kremenetskiy Forestry College, 1, Molodizhna st., Bilokrynytsya, Ternopilregion, 47014, Ukraine. Tel: 03546-52-404; +38-096-367-15-16.E-mail: kaleniukyurii@ gmail.com of the West Podillya. The share of oak and lime in their composition varies from single trees to 10 units. The estimation of the natural regeneration of tree species amount was carried out by establishing in each site of 20 plots with an area of $4 \mathrm{~m}^{2}(2 \times 2 \mathrm{~m})$. Selfseeding and advance growth plants were assessed and grouped according to species, physiological condition and age groups. The advance growth up to $0.50 \mathrm{~m}$ in height is considered to be small, $0.51-1.50 \mathrm{~m}-$ medium, and $1.51 \mathrm{~m}$ and above - large. According to the physiological condition, the advance growth is divided into healthy, moderately weakened and much weakened plants. It is found that natural regeneration in the stands is mostly unsatisfactory. The total number of natural regeneration of tree species in the advance growth ranges from 1.13 to 10.27 thousand plants / ha. Its species composition includes English and red oak, common ash, Norway maple and sycamore, European white elm, hornbeam, small-leaved lime, rowan tree, and beech. It was found that the age structure in the majority of the study plots is dominated by the 1-3-year-old advance growth. In $59 \%$ of the stands, its proportion is $50-100 \%$, while in other it varies within 28.6-48.4\%. Among the tree species, Norway maple and sycamore, hornbeam and elm are the best to regenerate. Their advance growth under the canopy of the parent stands reaches 4-8 years old and older. Oak advance growth of 1-3 years old was found in $72.3 \%$ of the plots $(0.25-2.63$ thousand plants / ha). Lime advance growth of seed origin occurs in $45.5 \%$ of the study stands and is $0.25-1.38$ thousand plants / ha with proportion 5.6-35.0\%. The frequency of advance growth occurrence in the forest stands is $30-95 \%$. Among the tree species, the lowest rates of occurrence are characteristic of the advance growth of small-leaved lime. The amount of small advance growth in different plots varies from 50 to $100 \%$. Among the tree species, the entire advance growth of common and red oak, common ash and beech belong to the small one which does not exceed $25 \mathrm{~cm}$. In the forest stands, the moderately weakened (41.1-54.1\%) young growth is prevalent and, to a large extent, the very weakened (19.1-41.8\%) advance growth of tree species is present. The share of healthy advance growth in the stands varies within 14.0-30.5\%. Natural seed regeneration of small-leaved lime is found on $38 \%$ of the investigated 1-5-year-old cutover areas. The advance growth of lime on 1-year-old cutovers occurs in $50 \%$ of the plots, on 2- and 3-year-olds - in $40 \%$, and on 4-5-year-olds - in 30\%. Its quantity ranges from 55 to 275 pcs per hectare. The average height of lime seedlings increases with age from $13.2 \mathrm{~cm}$ on 1-year-old cutover areas to $40.6 \mathrm{~cm}$ on 5-year-old cutover areas. The viability of lime nuts in different years of observation remains largely high and ranges from 55 to $94 \%$.

Key words: self-seeding; advance growth; viability of nuts; occurrence; physiological state; species composition. 